\title{
Jurnal Kesehatan Mercusuar
}

Avalilable Online http://jurnal.mercubaktijaya.ac.id/index.php/mercusuar

\section{PENGARUH LATIHAN JALAN KAKI TERHADAP KUALITAS TIDUR PADA PASIEN KANKER PAYUDARA YANG MENJALANI KEMOTERAPI DI RSUP DR. M DJAMIL PADANG}

\author{
Weny Amelia ${ }^{1^{*}}$, Mira Andika ${ }^{2}$, Diana Yulanda ${ }^{3}$ \\ 1,2,3 Program Studi S1 Keperawatan STIKes MERCUBAKTIJAYA Padang \\ Jl. Jamal Jamil Pondok Kopi Siteba Padang \\ *Email: wenyamelia.wa@gmail.com
}

\begin{abstract}
Chemotherapy is one of the modalities of cancer treatment to overcome the local stage and metastasis. The problem that often arises in breast cancer patients undergoing chemotherapy is sleep disorders that affect the patient's sleep quality. Decreased sleep quality experienced by breast cancer patients undergoing chemotherapy can be overcome by walking exercises. Walking exercises are activities or activities carried out using both legs followed by swinging hands or parts of the body synergistically. The purpose of this study was to look at the effect of walking training on sleep quality in breast cancer patients undergoing chemotherapy.This research was conducted at Dr. M. Djamil Hospital. When this study began on September 4-9, 2019. This study used a pre-experimental design with one group pretestposttest design. Data collection was carried out using a PSQI (Pittsburgh Quality Index) questionnaire to determine the quality of sleep of patients in the form of 30 minutes of walking exercises performed 3 times in 3 days. The results of the study with the statistical test paired sample t-test found that the average sleep quality score before the intervention was 12.16 and the average sleep quality score after the intervention was 7.16. This study found a significant difference in the improvement of sleep quality before and after the intervention $p$ value $=0,000$ $(p<0.05)$ so that it can be concluded that there is an effect of walking exercise on the sleep quality of breast cancer patients undergoing chemotherapy. It is recommended to nurses to provide education on walking exercises to breast cancer patients undergoing chemotherapy to improve the quality of sleep of patients, so as to improve the general health condition of patients.
\end{abstract}

Keywords: Breast Cancer, Chemotherapy, Sleep Quality, Walking Exercise

\begin{abstract}
ABSTRAK
Kemoterapi merupakan salah satu modalitas pengobatan kanker untuk mengatasi stadium lokal maupun metastase. Masalah yang sering muncul pada pasien kanker payudara yang menjalani kemoterapi adalah gangguan tidur sehingga berpengaruh terhadap kualitas tidur pasien. Penurunan kualitas tidur yang dialami oleh pasien kanker payudara yang menjalani kemoterapi dapat diatasi dengan latihan jalan kaki. Latihan jalan kaki merupakan kegiatan atau aktivitas yang dilakukan dengan menggunakan kedua kaki yang diikuti dengan ayunan tangan atau bagian anggota tubuh secara sinergis. Tujuan penelitian ini adalah untuk melihat pengaruh
\end{abstract}


latihan jalan kaki terhadap kualitas tidur pada pasien kanker payudara yang menjalani kemoterapi. Penelitian ini dilakukan di RSUP Dr. M. Djamil Padang. Waktu penelitian ini dimulai pada tanggal 4-9 September 2019. Penelitian ini menggunakan pre eksperiment design dengan rancangan one group pretest-posttest design. Pengumpulan data dilakukan dengan menggunakan kuesioner PSQI (Pittsburgh Quality Index) untuk mengetahui kualitas tidur pasien berupa latihan jalan kaki selama 30 menit dilakukan 3 kali dalam 3 hari. Hasil penelitian dengan uji statistik uji paired sampel t-test didapatkan bahwa rata-rata skor kualitas tidur sebelum intervensi 12.16 dan rata-rata skor kualitas tidur setelah intervensi 7.16. Penelitian ini menemukan perbedaan bermakna peningkatan kualitas tidur sebelum dan setelah intervensi $p$ value $=0,000(\mathrm{p}<0.05)$ sehingga dapat disimpulkan bahwa terdapat pengaruh latihan jalan kaki terhadap kualitas tidur pasien kanker payudara yang menjalani kemoterapi. Disarankan kepada perawat untuk memberikan edukasi latihan jalan kaki kepada pasien kanker payudara yang menjalani kemoterapi untuk meningkatkan kualitas tidur pasien, sehingga dapat meningkatkan kondisi kesehatan pasien secara umum.

Kata Kunci : Latihan Jalan Kaki, Kualitas Tidur, Kanker Payudara, Kemoterapi

\section{PENDAHULUAN}

Kanker merupakan salah satu penyakit yang termasuk dalam kelompok penyakit tidak menular atau disebut dengan Non-communcable diseases (NCD) (Marliana, 2018). Kanker terjadi karena hasil disfungsi Deoxyribo Nucleic Acid (DNA) yang menyebabkan pertumbuhan sel meningkat secara signifikan dan terjadinya proliferasi (Dewi et al., 2018). Kanker termasuk penyakit yang kurang disadari oleh sebagian masyarakat dan kurangnya melakukan deteksi dini kanker. Oleh karena itu, sebagian besar kanker ditemukan pada stadium lanjut sehingga sulit untuk ditanggulangi (Setiawan, 2015).

Kanker merupakan penyakit dengan angka kematian cukup tinggi di dunia. Menurut World Health Organization tahun 2014 kanker adalah penyebab kematian nomor 2 setelah penyakit kardiovaskuler yaitu $13 \%$ atau sekitar 8,2 juta orang di dunia. Sedangkan menurut GLOBOCAN International Agency for Research on Cancer (IARC) menyebutkan angka kejadian kanker di dunia pada tahun 2018 terdapat 18,1 juta kasus baru dengan angka kematian sebesar 9,6 juta kematian.
Angka kejadian penyakit kanker di Indonesia adalah sebesar 136,2 per 100.000 penduduk berada pada urutan 8 di Asia Tenggara. Jenis kanker yang paling banyak menyerang masyarakat Indonesia berbeda pada tiap jenis kelaminnya. Jenis kanker yang paling banyak menyerang laki-laki adalah kanker paru-paru sebanyak 19,4 per 100.000 penduduk. Jenis kanker yang paling banyak menyerang perempuan yaitu kanker payudara sebanyak 42,1 per 100.000 penduduk (Kemenkes RI , 2018)

Kanker payudara merupakan suatu kondisi dimana sel telah kehilangan pengendalian dan mekanisme normalnya, sehingga terjadi pertumbuhan yang abnormal, cepat dan tidak terkendali yang terjadi di jaringan payudara (Mulyani, 2013). Kanker bisa mulai tumbuh di dalam kelenjar susu, saluran susu, jaringan lemak maupun jaringan ikat pada payudara (Rahayu, 2016). Kanker payudara biasanya terjadi pada kelompok perempuan pasca menoupouse, tetapi saat ini banyak ditemukan pada usia muda lebih kurang 25 tahun (Kemenkes RI, 2015).

Menurut (American Cancer Society, 2015) didapatkan data kasus in situ pada kanker payudara sebanyak 
60.290 kasus, yang membutuhkan perawatan invasif sebanyak 231.840 kasus dan kematian akibat kanker payudara sebanyak 40.290 kasus. Data GLOBOCAN International Agency for Research on Cancer (IARC) tahun 2018, diketahui perkiraan jumlah kasus baru kanker payudara sekitar 2.088.849 (11.6\% dari semua kanker) dengan angka kematian 626.679 (6.6\%).

Angka kejadian kanker payudara di wilayah Indonesia salah satunya di Provinsi Sumatera Barat mengalami peningkatan pesat. Menurut Kemenkes RI tahun 2015 kejadian kanker payudara di Provinsi Sumatera Barat berada pada urutan nomor 3 tertinggi dengan persentase $0,9 \%$ dan estimasi jumlah penderita kanker payudara sebesar 2.285 kasus. Sedangkan pada tahun 2017 kejadian kanker payudara di Provinsi Sumatera Barat mengalami peningkatan menjadi urutan nomor 2 tertinggi di Indonesia yaitu sebesar 9,34\% setelah Provinsi Kepulauan Bangka Belitung yaitu 13,19\% (Kemenkes RI, 2018).

Berdasarkan data dari Dinas Kesehatan Kota Padang tahun 2015 angka kejadian kanker payudara adalah sebanyak $69 \%$ atau sekitar 241 kasus. Pada tahun 2016 mengalami peningkatan sebanyak $73 \%$ atau sekitar 438 kasus (Profil Kesehatan Kota Padang, 2016) . Menurut (Profil Kesehatan Sumatera Barat, 2017) hasil dari deteksi dini kanker payudara dengan pemeriksaan Clinical Breast Examination (CBE) terhadap 10.670 perempuan pada umur 30-50 tahun didapatkan $1,33 \%$ atau sekitar 142 orang mengalami kanker payudara.

Kemoterapi menjadi pilihan pertama untuk menangani kanker dikarenakan kemoterapi diberikan melalui pembuluh darah sehingga lebih efektif untuk menjangkau sel-sel kanker yang telah bermestastase ke jaringan lainnya dan dapat memberikan prognosis yang baik pada pasien (Anita \& Sukamti P, 2016).

Angka kejadian pasien kanker payudara yang menjalani kemoterapi di RSUP Dr. M. Djamil Padang pada tahun 2017 sebanyak 423 pasien. Angka ini mengalami peningkatan pada tahun 2018 menjadi sebanyak 540 pasien (Rekam Medis RSUP. Dr. M. Djamil Padang, 2018).

Pengobatan secara kemoterapi akan menimbulkan efek samping terhadap pemakainya karena obat kemoterapi yang sangat kuat dan sitostatika (Anita \& Sukamti P, 2016). Efek samping kemoterapi akan berpengaruh baik secara fisik maupun psikologis pasien kanker. Efek samping kemoterapi terhadap fisik paling umum terjadi yaitu supresi sumsum tulang belakang, mukositis, mual dan muntah, kelelahan, diare, rambut rontok, infeksi, dan infertilitas. Sedangkan secara psikologis adalah ketidakberdayaan, kecemasan, rasa malu, depresi dan stres (Handayani \& Udani, 2016).

Beberapa penelitian yang dikutip pada penelitian (Handayani \& Udani, 2016) menunjukkan bahwa efek kemoterapi dapat memperburuk status fungsional setelah pemberian kemoterapi. Penurunan status fungsional tersebut termasuk pemenuhan kebutuhan istirahat tidur.

Berdasarkan penelitian (Hananta et al., 2014) didapatkan pasien kanker payudara yang menjalani kemoterapi mengalami gangguan tidur sebanyak 63\% atau 518 pasien. Menurut penelitian (Alifiyanti et al., 2017) pasien kanker payudara yang menjalani kemoterapi di RSUP. Dr. Hasan Sadikin Bandung memiliki kualitas tidur yang buruk karena mual, muntah, dan diare sehingga sering terbangun pada malam hari dan mengantuk pada siang hari. Menurut (Week, 2015) pasien kanker 
payudara yang menjalani kemoterapi memiliki kualitas tidur yang buruk yaitu $67 \%$ dari 252 pasien akibat lelah, nyeri, dan stres psikologis.

Pasien kanker payudara yang menjalani kemoterapi mengalami gangguan tidur maka dapat menurunkan sistem kekebalan tubuh untuk melawan sel kanker yang sedang berkembang. Sebagai respon pertahanan diri, otak akan menahan produksi hormon melatonin untuk menggantinya dengan lebih banyak hormon stres seperti kortisol dan adrenalin. Melatonin dapat meningkatkan fungsi kekebalan tubuh. Ketika tubuh tidak memproduksi cukup melatonin, sistem imun akan kesulitan untuk mencegah kerusakan sel dan jaringan yang diakibatkan oleh kemoterapi (Potter \& Perry's, 2012).

Beberapa penatalaksanaan yang dapat dilakukan untuk meningkatkan kualitas tidur pada pasien kanker payudara yang menjalani kemoterapi seperti terapi farmakologi dan terapi non farmakologi. Terapi farmakologi merupakan terapi yang digunakan dengan obat-obatan. Namun pemakaian yang berlebihan pada obat-obatan akan memberi efek samping seperti kecanduan dan overdosis. Sedangkan terapi non farmakologi adalah terapi yang tidak menggunakan obat-obatan seperti terapi musik, massage, terapi perilaku kognitif, dan terapi aktifitas fisik (Subandi, 2017) .

Aktivitas fisik adalah gerakan fisik yang melibatkan otot-otot tubuh yang memerlukan pengeluaran energi. Aktivitas fisik merupakan bagian yang tidak terpisahkan dari penatalaksanaan penyakit kronis yang bertujuan untuk meminimalkan dampak negatif dari penyakit. Bentuk aktivitas fisik yang dapat dilakukan untuk pasien kanker payudara yang menjalani kemoterapi di rumah dan di rumah sakit yaitu berjalan dalam waktu tertentu seperti jogging, bersepeda, senam, dan latihan jalan kaki (Arovah, 2015).

Latihan jalan kaki merupakan tindakan berjalan biasa dengan tangan diayunkan dan tindakan ini sangat baik dan cocok untuk segala umur (Yitno \& Riawan Wahyu, 2017). Aktivitas fisik seperti latihan jalan kaki yang teratur berguna untuk mempertahankan dan memperbaiki kesegaran jasmani termasuk kualitas tidur pada pasien kanker yang menjalani kemoterapi apabila dilakukan 2-7 kali dalam seminggu dengan lamanya kurang lebih 30-40 menit per hari (Tang MF, Chiu $\mathrm{HY}, \mathrm{Xu} \mathrm{X}$, Kwok JY, Cheung DST, Chen CY, 2019). Latihan jalan kaki dapat dilakukan kapan saja tanpa tergantung cuaca, namun latihan kaki lebih baik dilakukan pada pagi hari dikarenakan udara yang masih bersih dan bebas polusi (Wahyuningsih, 2016).

Penelitian mengenai latihan jalan kaki telah dilakukan oleh (Chen et al., 2016) dengan judul "Effect of Walking on Circadian Rhythms and Sleep Quality of Patients with Lung Cancer: a Randomised Controlled Trial" dengan menunjukkan perbedaan yang signifikan antara kelompok intervensi dan kelompok kontrol pasien kanker yang mengalami gangguan tidur. Perubahan nilai Pisttsburgh Sleep Quality Index (PSQI) seperti gangguan tidur, penggunaan obat tidur, dan kualitas tidur sehingga didapatkan bahwa ada pengaruh signifikan antara latihan jalan kaki dengan gangguan tidur pasien kanker paru.

Penelitian lain juga dilakukan oleh (Yoh et al., 2018) dengan judul "Implication of exercise interventions on sleep disturbance in patients with pancreatic cancer: a study protocol for a randomised controlled trial" dengan menunjukkan pasien kanker pankreas selama menjalani pengobatan 
kemoterapi kebutuhan tidurnya relatif kurang sebelum dilakukan latihan fisik. Kebutuhan tidur pasien kanker pankreas sesudah dilakukan latihan fisik menunjukkan kebutuhan tidur yang baik.

Pengaruh latihan jalan kaki dapat merangsang hipotalamus untuk menstimulasi kelenjer hipofisis anterior. Kelenjer hipofisis anterior berfungsi untuk mencegah adanya infeksi, memacu terjadinya tidur, dan memperkuat mood seseorang. Pada saat terjadinya stimulasi kelenjer hipofisis anterior maka terjadinya peningkatan sekresi beta endorphin oleh hipotalamus. Beta endorphin yang dihasilkan dapat menimbulkan perasaan rileks, tenang, nyaman, dan senang. Ketika tubuh merasakan perasaan tersebut, maka frekuensi gelombang otak akan menurun, dan sistem Bulbar Synchronizing Regional (BSR) akan naik, sehingga mampu membantu istirahat tidur menjadi lebih baik dan dapat meningkatkan kualitas tidur seseorang (Potter \& Perry's, 2012). Pada saat tersebut, tingkat kelelahan pasien akan dipulihkan (Rizka \& Agus, 2018).

Berdasarkan hasil survey awal yang dilakukan peneliti pada 5 orang pasien kanker payudara di ruang kemoterapi RSUP. Dr. M. Djamil Padang, hampir semua pasien kanker payudara yang menjalani kemoterapi atau 5 orang yang sudah diwawancarai memiliki keluhan yang sama setelah dilakukan kemoterapi yaitu merasa mual, muntah, lemas, kelelahan, nafsu makan menurun, dan gangguan tidur. Berdasarkan fenomena diatas maka penulis tertarik melakukan penelitian tentang pengaruh latihan jalan kaki terhadap kualitas tidur pada pasien kanker payudara yang menjalani kemoterapi di RSUP Dr. M. Djamil Padang.

\section{METODE PENELITIAN}

Jenis penelitian ini adalah pre eksperimen design dengan rancangan one group pretest-posttest design. Dalam penelitian ini sampel berjumlah 12 responden dengan kriteria inklusi : dapat berjalan sendiri tanpa bantuan, didiagnosis kanker payudara stadium I IIIB, menjalani kemoterapi adjuvant siklus 1, umur 40- 60 tahun, bisa berkomunikasi dengan baik (Kooperatif), tekanan rarah : sistole 100-140 mmHg; diastole ; 60-90 mmHg ; nadi : 60-100 x/menit, dan PSQI > 5. Sedangkan kriteria ekslusi dalam penelitian ini adalah responden yang mempunyai kelainan dan gangguan jantung dan mengkonsumsi obat tidur.

\section{HASIL DAN PEMBAHASAN}

1. Rerata Kualitas tidur Sebelum Dilakukan Latihan Jalan kaki Pada Pasien Kanker Payudara yang Menjalani Kemoterapi di RSUP. Dr. M. Djamil Padang Tahun 2019

Tabel 1.

Kualitas tidur Sebelum Dilakukan Latihan Jalan kaki Pada Pasien Kanker Payudara yang Menjalani Kemoterapi di RSUP. Dr. M. Djamil Padang Tahun 2019

\begin{tabular}{cccccc}
\hline $\begin{array}{c}\text { Kualitas } \\
\text { tidur }\end{array}$ & n & Mean & SD & Min & Max \\
\hline Pretest & 12 & 12.16 & 1.52 & 9 & 14 \\
\hline
\end{tabular}

Berdasarkan pada tabel di atas dapat dilihat bahwa dari 12 pasien kanker payudara yang menjalani kemoterapi sebelum diberikan latihan jalan kaki didapatkan rata-rata skor kualitas tidur adalah 12.16 dengan standar deviasi 1.52 Penelitian ini hampir sama dengan penelitian yang 
dilakukan oleh (Chen et al., 2016) tentang Effect of walking on circadian rhythms and sleep quality of patients with lung cancer: a randomised controlled trial. National Taipei University of Nursing and Health Sciences, dimana didapatkan nilai ratarata skor tidur sebelum diberikan intervensi adalah 12,27 ini juga dikatakan kualitas tidur pasien kanker paru-paru yang buruk.

Kualitas tidur yang buruk dipengaruhi oleh berbagai hal yaitu gangguan fisik berupa respon dari penyakit, respon dari kemoterapi serta gangguan mental dan spiritual berupa perasaan ketidakberdayaan, putus asa dan penolakan terhadap kenyataan sakit yang dihadapi. Pada pasien kanker payudara yang menjalani kemoterapi mengalami respon dari efek samping kemoterapi baik secara fisiologis dan psikologis. Hal ini dikarenakan obat kemoterapi yang sangat kuat dan sitostatika. Efek samping kemoterapi terhadap fisiologis paling umum terjadi yaitu supresi sumsum tulang belakang, mukositis, mual dan muntah, kelelahan, diare, rambut rontok, infeksi, dan infertilitas. Sedangkan secara psikologis adalah ketidakberdayaan, kecemasan, rasa malu, depresi, dan stres. Sehingga efek ini sering kali menganggu pola tidur pasien (Handayani \& Udani, 2016).

Berdasarkan data pretest dari 7 komponen kualitas tidur ditemukan bahwa komponen yang paling bermasalah yaitu pada gangguan aktivitas siang hari (89\%), kemudian dikuti oleh efisiensi tidur (78\%), kualitas tidur subjektif (67\%), dan gangguan tidur $(61 \%)$. Gangguan tidur yang dialami oleh reponden pada umumnya adalah terbangun ditengah malam atau terlalu pagi $\geq 3 \mathrm{x}$ seminggu sebanyak $(58.3 \%)$ dan $>2 x$ seminggu $(41,7 \%)$ responden, selanjutnya terbangun ke kamar mandi $\geq 3 \mathrm{x}$ seminggu sebanyak (83\%) responden dan $>2 x$ seminggu $(17 \%)$ responden.

Data tersebut sejalan dengan penelitian yang dilakukan oleh (Alifiyanti et al., 2017) tentang kualitas tidur pasien kanker payudara berdasarkan terapi yang diberikan di RSUP Dr. Hasan Sadikin Bandung didapatkan bahwa komponen gangguan tidur yang bermasalah pada pasien kanker yang menjalani kemoterapi adalah terbangun ditengah malam atau terlalu pagi $(82 \%)$ dan diikuti $(80 \%)$ responden mengalami gangguan aktivitas siang hari.

Menurut analisa peneliti, dari hasil pengumpulan data yang telah dilakukan pada 12 pasien kanker payudara yang menjalani kemoterapi di RSUP Dr. M. Djamil Padang, terdapat perbedaan skor kualitas tidur yang ditunjukkan oleh masing-masing responden. Bila dilihat dari karakteristik usia, dimana usia responden rata-rata 50 tahun dengan usia termuda 40 tahun dan tertua 59 tahun. Menurut penelitian (Handayani \& Udani, 2016) menyatakan bahwa efesiensi tidur pada pasien kanker mencapai 80\%-90\% pada usia diatas 40 tahun.

Dilihat dari karakteristik jenis kelamin responden, data penelitian menunjukkan bahwa 12 responden berjenis kelamin perempuan. Hal ini menunjukan bahwa penyakit kanker payudara cendrung terjadi pada jenis kelamin perempuan. Menurut penelitian (Mulyani, 2013) menyatakan kanker payudara umumnya menyerang kaum wanita dan kemungkinan menyerang kaum laki-laki sangat kecil yaitu 1: 1000. Pada karakteristik lama menjalani kemoterapi cendrung lebih banyak yaitu 8 kali kemoterapi (25\%), kemoterapi ke 7 kali (25\%), kemoterapi ke 6 kali $(16,7 \%)$, kemoterapi ke 5 kali $(8,3)$, kemoterapi ke 4 kali (8,3\%), 
kemoterapi ke 3 kali $(8,3 \%)$ dan kemoterapi ke 2 kali (8,3\%). Pada penelitian Alifianti (2017), menyatakan bahwa semakin lama pasien menjalani kemoterapi maka kualitas tidur pasien semakin buruk.

$$
\text { Berdasarkan hasil penelitian }
$$

dapat disimpulkan bahwa responden

yang mengalami kesulitan untuk memulai tidur dipengaruhi oleh berbagai gangguan tidur yang dialami responden yaitu kelelahan $83 \%$, mual muntah $75 \%$, sering terbangun ke kamar mandi sebanyak $83 \%$ dan $83 \%$ kepanasan dimalam hari sehingga butuh waktu lama untuk responden memulai tidur. Gangguan tidur tersebut juga mempengaruhi kedalaman tidur responden. Beberapa dari gangguan tidur tersebut membuat responden terbangun ditengan malam dan responden mengalami kesulitan untuk tidur kembali.

\section{Rerata Kualitas tidur Sesudah} Dilakukan Latihan Jalan kaki Pada Pasien Kanker Payudara yang Menjalani Kemoterapi di RSUP. Dr. M. Djamil Padang Tahun 2019

Tabel 2.

Kualitas tidur Sesudah Dilakukan Latihan Jalan kaki Pada Pasien

Kanker Payudara yang Menjalani Kemoterapi di RSUP. Dr. M. Djamil Padang Tahun 2019

\begin{tabular}{cccccc}
\hline $\begin{array}{c}\text { Kualitas } \\
\text { tidur }\end{array}$ & n & Mean & SD & Min & Max \\
\hline Posttest & 12 & 7.16 & 1.69 & 5 & 10 \\
\hline
\end{tabular}

Berdasarkan tabel diatas dapat dilihat bahwa dari 12 pasien kanker payudara yang menjalani kemoterapi sesudah diberikan latihan jalan kaki didapatkan rata-rata skor kualitas tidur adalah 7.16 dengan standar deviasi 1.69 Dari data tersebut didapatkan bahwa rata-rata skor kualitas tidur setelah intervensi mengalami penurunan. Hal ini dapat dikatakan kualitas tidur responden meningkat.

Penelitian ini hampir sama dengan penelitian yang dilakukan oleh (Chen et al., 2016) tentang Effect of walking on circadian rhythms and sleep quality of patients with lung cancer: a randomised controlled trial. National Taipei University of Nursing and Health Sciences, dimana didapatkan nilai ratarata skor kualitas tidur setelah diberikan intervensi adalah 8.0, angka tersebut menunjukan bahwa terjadi penurunan skor kualitas tidur setelah diberikan intervensi jalan kaki, hal ini juga dapat dikatakan kualitas tidur responden meningkat.

Kualitas tidur yang baik ditentukan oleh bagaimana seseorang mempersiapkan pola tidurnya pada malam hari seperti kedalaman tidur dan kemudahan untuk tertidur tanpa bantuan medis. Kualitas tidur yang baik diperlihatkan dengan mudahnya seseorang memulai tidur, mempertahankan tidur, dan peralihan dari tidur kebangun di pagi hari dengan mudah (Potter \& Perry's, 2012).

Berdasarkan penelitian yang peneliti lakukan kepada pasien kanker payudara yang menjalani kemoterapi di RSUP. Dr. M. Djamil Padang didapatkan bahwa terjadi penurunan skor kualitas tidur setelah diberikan intervensi. Hal ini dapat dilihat dari hasil kuesioner $16,7 \%$ responden mengalami kualitas tidur membaik dan $83 \%$ responden mengalami peningkatan pada kualitas tidurnya. Penurunan skor kualitas tidur terjadi pada masing masing komponen. Komponen pertama yaitu kualitas tidur subyektif yang dilihat dari pernyataan responden mengenai kualitas tidurnya secara keseluruhan. Pada penelitian ini terdapat responden yang mengalami penurunan skor kualitas tidur subyektif 
setelah dilakukan latihan jalan kaki selama 3 hari.

Hasil ini sesuai dengan penelitian (Yoh et al., 2018) tentang implication of exercise interventions on sleep disturbance in patients with pancreatic cancer yang melaporkan terdapat $70 \%$ responden yang mengalami penurunan skor kualitas tidur subyektif. Komponen lama tidur dilihat dari beberapa lama responden dapat tidur nyenyak dimalam hari. Pada penelitian ini sudah dilakukan intervensi didapatkan $\quad 41,7 \% \quad$ responden mengalami penurunan skor setelah dilakukan intervensi.

Berdasarkan hasil wawancara oleh peneliti dari kuesioner PSQI terdapat $83.3 \%$ responden mengalami peningkatan pada kualitas tidurnya dan $16.7 \%$ kualitas tidurnya membaik. Dari hasil penelitian penurunan skor terjadi pada komponen gangguan tidur $(58,3 \%)$, kemudian diikuti oleh lama waktu tidur $(50 \%)$, efisiensi tidur $(58,3 \%)$, waktu tidur $(41,7 \%)$.

Hasil ini sejalan dengan penelitian (Tang, M. F., Liou, T. H., \& Lin, 2010) tentang improving sleep quality for cancer patients: benefits of a home based exercise intervention bahwa penurunan skor kualitas tidur paling banyak terjadi pada komponen gangguan tidur (59\%), kualitas tidur subyektif (43\%), lalu diikuti dengan aktifitas siang hari (40\%).

Menurut analisa peneliti peningkatan kualitas tidur yang dialami oleh responden karena adanya intervensi yang diberikan yaitu latihan jalan kaki. Menurut (Potter \& Perry's, 2012) terapi aktifitas fisik seperti latihan jalan kaki yang bermanfaat untuk mengatasi gangguan kebutuhan tidur. Hal ini bisa dilihat pada saat peneliti melakukan pengukuran kualitas tidur setelah dilakukan intervensi yaitu pertanyaan mengenai pendapat responden tentang bagaimana kualitas tidurnya, dilihat dari jawaban tersebut didapatkan bahwa $16,7 \%$ responden mengatakan kualitas tidurnya baik dan $83 \%$ mengatakan kualitas tidurnya meningkat. Kualitas tidur yang baik disebabkan karena kepatuhan atau ketetapan waktu responden untuk melakukan latihan jalan kaki, kepedulian responden terhadap diri sendiri serta menjaga kesehatan untuk terhindar dari berbagai penyakit.

\section{Pengaruh Latihan Jalan Kaki Terhadap Kualitas Tidur Pada Pasien Kanker Payudara yang Menjalani Kemoterapi di RSUP Dr. M. Djamil Padang 2019}

Tabel 3.

Pengaruh Latihan Jalan Kaki

Terhadap Kualitas Tidur Pada

Pasien Kanker Payudara yang

Menjalani Kemoterapi di RSUP Dr.

M. Djamil Padang Tahun 2019

\begin{tabular}{ccccc}
\hline $\begin{array}{c}\text { Kelom- } \\
\text { Pok }\end{array}$ & $\begin{array}{c}\text { Selisih } \\
\text { mean }\end{array}$ & SD & $\begin{array}{c}\text { 95\% CI } \\
\text { Lower } \\
\text { Upper }\end{array}$ & $\begin{array}{c}\boldsymbol{p} \\
\text { value }\end{array}$ \\
\hline $\begin{array}{c}\text { Pretest- } \\
\text { posttest }\end{array}$ & 5.0 & 2.37 & 3.49 & 0.000 \\
\hline
\end{tabular}

Berdasarkan tabel diatas
menunjukan hasil uji menggunakan paired sampel t-test didapatkan nilai $p$-value $0,000(\mathrm{p}<0,05)$ dan didapatkan selisih nilai rata-rata skor kualitas tidur sebelum dilakukan intervensi latihan jalan kaki dan sesudah dilakukan intervensi latihan jalan kaki sebesar 5.0. Hal ini membuktikan bahwa ada pengaruh latihan jalan kaki terhadap kualitas tidur pada pasien kanker payudara yang menjalani kemoterapi di RSUP. Dr. M.Djamil Padang. Berdasarkan hasil penelitian rata-rata kualitas tidur sebelum 
diberikan intervensi latihan jalan kaki adalah 12.16 dengan standar deviasi 1.52, sedangkan rata-rata kualitas tidur setelah intervensi latihan jalan kaki adalah 7.16 dengan standar deviasi 1.69. Dari hasil penelitian saat dilakukan uji statistik paired samples t-test didapatkan nilai $p$ value $=0,000$ $(\mathrm{p}<0,05)$, hal ini dapat disimpulkan bahwa secara statistik didapatkan terdapat pengaruh latihan jalan kaki terhadap kualitas tidur pada pasien kanker payudara yang menjalani kemoterapi di RSUP.Dr. M. Djamil Padang.

Hasil penelitian ini sejalan dengan penelitian yang dilakukan oleh (Tang, M. F., Liou, T. H., \& Lin, 2010) tentang improving sleep quality for cancer patients : benefits of a home based exercise intervention bahwa terdapat pengaruh latihan jalan kaki terhadap kualitas tidur pasien kanker. Hal ini terlihat di uji statistik dengan $p$ value $=0,01 \quad(\mathrm{p}<0,05)$. Pada penelitian (Chen et al., 2016) juga menyebutkan dalam penelitiannya tentang Effect of walking on circadian rhythms and sleep quality of patients with lung cancer: a randomised controlled trial. National Taipei University of Nursing and Health Sciences bahwa terdapat pengaruh latihan jalan kaki terhadap kualitas tidur pada pasien kanker paru. Hal ini terlihat pada uji statistik yang dilakukan dengan menggunakan uji paired sampel t- test dengan nilai signifikan $\mathrm{p}=0,001$ $(\mathrm{p}<0,05)$. Pemberian latihan jalan kaki efektif untuk mengatasi gangguan tidur pada pasien kanker paru-paru.

Hasil penelitian ini juga sejalan dengan penelitian yang dilakukan oleh (Yoh et al., 2018) dengan judul "Implication of exercise interventions on sleep disturbance in patients with pancreatic cancer: a study protocol for a randomised controlled trial" menunjukkan bahwa dalam posttest, hasil menunjukkan perbedaan yang signifikan antara kelompok intervensi dan kelompok kontrol mengenai nilai rata-rata PSQI. Pada kelompok intervensi, perbedaan signifikan yang ditemukan mengenai perubahan ratarata kualitas tidur, latensi tidur, gangguan tidur, disfungsi siang hari, penggunaan obat tidur dan kualitas tidur subyektif sebelum dan sesudah intervensi dengan p-value 0,009 $(\mathrm{p}<0,05)$.

Masalah gangguan tidur yang dialami oleh pasien kanker payudara yang menjalani kemoterapi dapat diatasi dengan menggunakan terapi latihan jalan kaki. Latihan jalan kaki merupakan kegiatan atau aktivitas yang dilakukan dengan menggunakan kedua kaki yang diikuti dengan ayunan tangan atau bagian anggota tubuh secara sinergis. Latihan jalan kaki dapat merangsang hipotalamus untuk menstimulasi kelenjer hipofisis anterior. Kelenjer hipofisis anterior berfungsi untuk mencegah adanya infeksi, memacu terjadinya tidur,dan memperkuat mood seseorang. Pada saat terjadinya stimulasi kelenjer hipofisis anterior maka terjadinya peningkatan sekresi beta endorphin oleh hipotalamus. Beta endorphin yang dihasilkan dapat menimbulkan perasaan rileks, tenang, nyaman, dan senang. Ketika tubuh merasakan perasaan tersebut, maka frekuensi gelombang otak akan menurun, dan sistem Bulbar Synchronizing Regional (BSR) akan naik, sehingga mampu membantu istirahat tidur menjadi lebih baik dan dapat meningkatkan kualitas tidur seseorang (Potter \& Perry's, 2012).

Teori lain menunjukkan bahwa kualitas tidur yang baik setelah dilakukan latihan jalan kaki dapat terjadi adanya kerja sama berbagai otot tubuh yang ditandai dengan perubahan kekuatan otot, kelenturan otot, 
kecepatan reaksi, ketangkasan, koordinasi gerakan, dan daya tahan sistem kardiorespirasi. Beberapa kondisi tersebut akan membuka sumbatansumbatandan memperlancar aliran darah ke jantung serta meningkatkan aliran darah yang lebih banyak pada otot-otot untuk mendukung metabolisme. Aliran darah yang meningkat juga dapat meningkatkan oksigen. Peningkatan oksigen didalam otak akan merangsang peningkatan serotonin sehingga membuat tubuh menjadi tenang dan lebih muda tidur (Guyton AC, 2010)

\section{SIMPULAN}

Berdasarkan hasil penelitian yang telah dilakukan didapatkan kesimpulan sebagai berikut :

1. Rata-rata skor kualitas tidur sebelum intervensi adalah 12.16, ini dapat dikatakan kualitas tidur pasien kanker payudara yang menjalani kemoterapi yaitu buruk.

2. Rata-rata skor kualitas tidur sesudah intervensi adalah 7.16 terjadi penurunan skor kualitas tidur setelah diberikan intervensi, ini dikategorikan pada kualitas tidur pasien meningkat dari sebelumnya.

3. Adanya pengaruh latihan jalan kaki terhadap kualitas tidur pada pasien kanker payudara yang menjalani kemoterapi di RSUP. Dr. M. Djamil Padang dengan nilai $p$-value $=0,000$ $(\mathrm{p}<0,05)$.

\section{UCAPAN TERIMAKASIH}

Peneliti menyampaikan ucapan terima kasih yang sedalam-dalamnya kepada yang terhormat:

1. Direktur RSUP Dr.M.Djamil Kemoterapi beserta perawat ruangan yang telah memberi izin untuk melakukan penelitian.
2. Responden kanker payudara yang menjalani kemoterapi yang telah bersedia menjadi Responden.

3. Ibu Ises Reni, Skp, M.Kep sebagai ketua STIKes MERCUBAKTIJAYA Padang.

4. Bapak Jasmarizal SKp, MARS sebagai ketua Yayasan STIKes MERCUBAKTIJAYA Padang.

5. Semua pihak yang telah memberi dukungan, bantuan dan motivasi dalam segala hal dalam penyelesaian penelitian ini.

\section{DAFTAR PUSTAKA}

Alifiyanti, D., Hermayanti, Y., \& Setyorini, D. (2017). Kualitas Tidur Pasien Kanker Payudara Berdasarkan Terapi yang Diberikan di RSUP DR. Hasan Sadikin Bandung. Jurnal Pendidikan Keperawatan Indonesia, 3(2), 115. https://doi.org/10.17509/jpki.v3i2. 9418

American Cancer Society. (2015). Chemotherapy Drugs : How They Work Understanding the life cycle of a cell. American Cancer Society. https://doi.org/22/10/2015

Anita, A., \& Sukamti P, T. (2016). Pengaruh Pemberian Booklet Kemoterapi terhadap Kemampuan Perawatan Diri Penderita Kanker Payudara Pasca Kemoterapi di Ruang Bedah Rumah Sakit Abdul Moeloek (RSAM) Bandar Lampung. Jurnal Kesehatan, 7(1), 26. https://doi.org/10.26630/jk.v7i1.1 15

Arovah, N. I. (2015). PRINSIP PEMROGRAMAN LATIHAN FISIK PADA PENYAKIT KRONIS. 1, 1-14.

Chen, H. M., Tsai, C. M., Wu, Y. C., Lin, K. C., \& Lin, C. C. (2016). Effect of walking on circadian 
rhythms and sleep quality of patients with lung cancer: A randomised controlled trial. British Journal of Cancer, 115(11), 1304-1312. https://doi.org/10.1038/bjc.2016.3 56

Dewi, P. F., Franz, Y., \& Kahija, L. (2018). Pengalaman Menderita Kanker Payudara Sebuah Interpretative Phenomenological Analysis. Empati, 7(1), 202-214.

Guyton AC, H. J. (2010). Buku Ajar Fisiologi Kedokteran. Jakarta: EGC.

Hananta, L., Benita, S., Barus, J., \& Halim, F. (2014). Gangguan Tidur Pada Pasien Kanker Payudara Di Rumah Sakit Dharmais Jakarta. Damianus Journal of Medicine.

Handayani, R. S., \& Udani, G. (2016). Kualitas tidur dan distress pada pasien kanker yang menjalani kemoterapi. Jurnal Keperawatan, XII(1), 66-72.

Kemenkes. (2015). Kementerian Kesehatan Republik Indonesia 2015. In Profil Kesehatan Indonesia 2014.

Kemenkes. (2018). Riset Kesehatan Dasar Indonesia tahun 2018. In Kementerian Kesehatan Republik Indonesia.

Kemenkes RI. (2018). Hasil Utama Riset Kesehatan Dasar 2018. Kementrian Kesehatan Republik Indonesia. $\quad$ https://doi.org/1 Desember 2013

Marliana, Y. (2018). Akurasi Metode Inspeksi Visual dengan Asam Asetat/IVA untuk Deteksi Dini Kanker Leher Rahim. Jurnal Kesehatan Prima, 8(2), 13361344.

Mulyani, N. S. (2013). Kanker Payudara dan PMS pada Kehamilan. Jakarta: Nuha Medika. https://doi.org/10.1117/12.474399

Potter \& Perry's. (2012). Potter and Perry's Fundamentals of Nursing. https://media.elsevierhealth.com.a u/media/blfa_files/Potter__Perry _Fund_of_Nursing_ANZ_978072 9541107_Crisp.pdf

Profil Kesehatan Kota Padang. (2016). Profil Kesehatan Sumatera Barat. (2017). Profil Kesehatan Sumatera Barat 2017. 12.

Rahayu, D. (2016). PENILAIAN TERHADAP STRESOR \& SUMBER KOPING PENDERITA KANKER YANG MENJALANI KEMOTERAPI. 18, 95-103.

Rekam Medis RSUP. Dr. M. Djamil Padang. (2018). Rekam Medis RSUP. Dr. M. Djamil Padang. Rekam Medis RSUP. Dr. M. Djamil. Padang: Rekam Medis RSUP. Dr. M. Djamil Padang.

Rizka, M., \& Agus, A. (2018). Pengaruh Latihan Jalan Kaki Terhadap Kebugaran Jasmani Lansia Di Puskesmas Sungai Aur Kabupaten Pasaman Barat. Jurnal Stamina, 1(1), 206-218. file:///D:/ANALISIS BAB VVII/SKRIPSI 2019-2020/project skripsi/moni proposal/Jurnal/53Article Text-68-1-1020190123.pdf

Setiawan, D. (2015). the Effect of Chemotherapy in Cancer Patient To Anxiety. Jurnal Majority, 4(4), 94-99.

http://juke.kedokteran.unila.ac.id/i ndex.php/majority/article/view/58 7

Subandi, E. (2017). Pengaruh Rendam Kaki Dengan Air Hangat Terhadap Kualitas Tidur Lansia di Desa Pakusamben Kecamatan Babakan Kabupaten Cirebon. Ilmu Kesehatan STIes Cirebon. Endang Subandi, 2(6), 31-44.

Tang, M. F., Liou, T. H., \& Lin, C. C. 
(2010). (2010). Improving sleep quality for cancer patients: Benefits of a home-based exercise intervention. Supportive Care in Cancer, 18(10), 1329-1339. https://doi.org/10.1007/s00520009-0757-5.

Tang MF, Chiu HY, Xu X, Kwok JY, Cheung DST, Chen CY, L. C. W. is more effective than yoga at reducing sleep disturbance in cancer patients: A. systematic review and meta-analysis of randomized controlled trials. S. M. R. 47: 1-8. P. 31207341 D. 10. 1016/j. smrv. 2019. 05. 00. (2019). Walking is more effective than yoga at reducing sleep disturbance in cancer patiesnts : A system review and meta-analysis of randomized controlled trials . doi:10.1016/j.smrv.2019.05.003.

Wahyuningsih, A. S. (2016). Membudayakan Jalan Kaki di Kampus Konservasi. Media Ilmu Keolahragaan Indonesia, 5(2), 51-56.

https://doi.org/10.15294/miki.v5i2 .7889

Week, B. (2015). Drugs and Therapies; Findings from Research Center Update Understanding of Chemotherapy ( Patients attitudes towards sleep disturbances during chemotherapy ). 23(July), 2014-2016.

Yitno, \& Riawan Wahyu, A. (2017). Pengaruh Jalan Kaki Ringan 30 Menit Terhadap Penurunan Kadar Gula Darah Pada Lansia Penderita Diabates Mellitus Tipe 2 di Desa Dukuh Kecamatan Gondang Kabupaten Tulungagung. STRADA Jurnal Ilmiah Kesehatan, 6(2), 8-15.

Yoh, K., Nishikawa, H., Enomoto, H., Ishii, N., Iwata, Y., Ishii, A., Yuri, Y., Miyamoto, Y., Hasegawa, K.,
Nakano, C., Takata, R., Nishimura, T., Aizawa, N., Sakai, Y., Ikeda, N., Takashima, T., Iijima, H., \& Nishiguchi, S. (2018). Implication of exercise interventions on sleep disturbance in patients with pancreatic cancer: A study protocol for a randomised controlled trial. BMJ Open Gastroenterology, 5(1), 22-25. https://doi.org/10.1136/bmjgast2017-000196 